\title{
Documentation on Enhancing Nutrient Uptake and Yield of Rice with Application of Sewage Sludge and Different Fertility Levels on Sodic Vertisols
}

\author{
Rahul Thakur ${ }^{1}$, U.R. Khandkar ${ }^{1}$, Debabrata Nath ${ }^{* 2}$, \\ Rohit K. Patidar ${ }^{2}$ and Narendra K. Patidar ${ }^{1}$ \\ ${ }^{1}$ Rajmata Vijayaraje Scindia Krishi Vishwavidyalaya (RVSKVV), College of Agriculture, \\ Indore Madhya Pradesh-452001, India \\ ${ }^{2}$ ICAR- Indian Institute of Soil Science, Nabibagh, Berasia Road, Bhopal, \\ Madhya Pradesh -462038, India \\ *Corresponding author
}

\section{A B S T R A C T}

A field experiment was conducted at salinity Research farm, Barwaha, District Khargone, Madhya Pradesh during Kharif season of 2014-15. The experiment comprised of 3 levels

Keywords

Sewage-sludge, RDF, Sodic vertisols, Nutrient uptake.

Article Info

Accepted:

26 September 2017

Available Online:

10 October 2017 of sewage sludge $\left(0,5\right.$ and $\left.10 \mathrm{t} \mathrm{ha}^{-1}\right)$ and 4 levels of fertility levels $(0,75,100$ and $125 \%$ RDF). Twelve treatments combination thus formed were laid out in Factorial Randomized Block Design with three replications. The total number of plots was 36. The results showed that the application of $10 \mathrm{t} \mathrm{ha}^{-1}$ sewage sludge singly and in combination with $100 \%$ RDF significantly increased the dry matter production at 30, 60 and 90 days growth and growth parameters such as plant height, 1000-grain weight (Test Weight), number of effective tillers and length of panicle. There was significant increase in grain yield of rice with application of sewage sludge. The grain yield of rice is increased by $27.9 \%$ at $10 \mathrm{t}$ $\mathrm{ha}^{-1}$ sewage sludge application. $100 \%$ RDF application increased the grain yield by $75.4 \%$ over control $\left(\mathrm{RDF}_{0}\right)$. The conjoint application of $10 \mathrm{t} \mathrm{ha}^{-1}$ sewage sludge and $100 \%$ produced the highest grain yield $\left(2306.5 \mathrm{~kg} \mathrm{ha}^{-1}\right)$ of rice. Application of $10 \mathrm{t} \mathrm{ha}^{-1}$ sewage sludge significantly improved the concentration and uptake of $\mathrm{N}, \mathrm{P}, \mathrm{K}, \mathrm{Zn}, \mathrm{Mn}, \mathrm{Cu}$ and Fe by the grain. Application of $100 \%$ RDF significantly increased N, P and K concentration in grain.

\section{Introduction}

Sodic soils are highly problematic for crop production. The presence of high amount of soluble salts and exchangeable $\mathrm{Na}^{+}$in the soils are main factors that inhibit crop production. Two lakh forty two thousand hectares of land is affected by salinity and sodicity in Madhya Pradesh. Rice is generally required a good supply of major nutrients for growth and development of the crop. Crop grown on these soils invariably suffers from nutritional disorders (N, Ca, Zn, P, Mg deficiencies and
$\mathrm{Na}$ toxicity) resulting lower yield. Sodic soils are known to be low in organic matter and hence, poor in $\mathrm{N}, \mathrm{P}, \mathrm{Ca}, \mathrm{Mg}$, and $\mathrm{Zn}$ content.

Rice (Oryza sativa L.) is the most important crop in India and is also the hub of food security of the global population. At global level, rice is grown on an area of about 155.62 million ha with production and productivity of 461 million tonne and 4.09 tonne/ha, respectively. India ranks first in respect of 
area 44.50 million ha second in production 102.75 million tonne, only after China, but the productivity of rice is very low only 2.20 tonne ha ${ }^{-1}$ (Anonymous, 2012).

Sewage sludge is the residue obtained from domestic and industrial wastewater treatment. Increasing cost of commercial fertilizers and large amount of sewage sludge product worldwide have led to examine the option of land application of the residue as a source of organic matter and nutrients to soil. Sewage sludge is rich in organic matter and plant nutrients especially nitrogen, phosphorus, calcium and micronutrients (Singh and Agrawal 2008; Meena et al., 2008).

A lot of research work has been done on such aspect on paddy in normal soil, but the information for sodic Vertisolsare very limited.

Keeping this in view the present experiment is planned on the following main objectives: i) to see the effect of sewage sludge and fertility levels on growth and yield of rice. ii) To see the effect of sewage sludge and fertility levels on chemical composition of rice plant.

\section{Materials and Methods}

The present experiment was laid out at the Salinity Research Farm Barwaha District, Khargone under Salt Affected Soils Project, College of Agriculture, Indore (M.P.) India during kharif 2014-15.

\section{Processing of sewage sludge}

Sewage sludge used in the investigation was obtained from drying beds of sewer treatment plant at village Bhangarh district Indore Madhya Pradesh. The sewage sludge was also air dried, ground to pass $2 \mathrm{~mm}$ sieve and stored in a sealed plastic container at $4{ }^{\circ} \mathrm{C}$ for further chemical analysis (Table 1).

\section{Chemical analyses of plant samples}

\section{Collection of plant sample}

Five plant sample were selected randomly at 30, 60 and 90 days after planting and at harvest from each plot. The plant and grain samples were dried at $65^{\circ} \mathrm{C}$ for 48 hours in an oven and dry weights were recorded.

The plant and grain samples were powdered in Wiley Mill and preserved for nutrient analysis.

\section{Wet digestion of plant sample}

Wet digestion of one gram oven dry sample was done by a di-acid (3:1 viz., $\mathrm{HNO}_{3}$ and $\mathrm{HClO}_{3}$ ) on a hot plate. After the complete digestion, the materials were allowed to cool and were filtered and the volume was made up to $100 \mathrm{ml}$ mark. This extract was preserved for all the determination except nitrogen.

\section{Nitrogen}

Nitrogen was determined by Kjeldahl's method using digestion mixture consisting of $\mathrm{CuSO}_{4}, \quad \mathrm{~K}_{2} \mathrm{SO}_{4}, \quad$ Selenium powder and $\mathrm{H}_{2} \mathrm{SO}_{4}$.Half-a-gram plant sample was digested in a block digestion unit.

After complete digestion the samples were distilled using micro-kjeldahl unit and the liberated ammonia was trapped in boric acid containing mixed indicator and titrated against $0.01 \mathrm{~N} \mathrm{H}_{2} \mathrm{SO}_{4}$ (Jackson, 1973).

\section{Phosphorus}

Phosphorus was determined by vanadomolybdate phosphoric acid yellow colour method and the colour intensity of yellow colour was recorded on spectrophotometer at $470 \mathrm{~nm}$ wave length (Jackson, 1973). 


\section{Potassium}

Potassium in the plant sample was estimated by atomizing the diluted plant extract in the flame photometer as described by Jackson (1973).

\section{Zinc, manganese, cupper and iron}

$\mathrm{Zn}, \mathrm{Mn}, \mathrm{Cu}$ and $\mathrm{Fe}$ in the plant extract were estimated by atomic absorption spectrophotometer.

\section{Results and Discussion}

\section{Dry matter yield and growth parameter}

\section{Dry matter yield (g plant ${ }^{-1}$ ) at 30 DAP}

The addition of increasing levels of sewage sludge significantly increased the dry matter yield of rice plant at 30 days. Application of sewage sludge @ $10 \mathrm{t} \mathrm{ha}^{-1}$ increased the dry matter yield of rice plant by $44.7 \%$ over control (Fig.1).

Application of successive levels of RDF significantly increased the dry matter yield up to $100 \%$ RDF. Further application of RDF did not increase the dry matter yield significantly. Application of $100 \%$ RDF increased the dry matter yield by $54.5 \%$ over control. Interaction between sewage sludge and RDF for dry matter yield of rice plant at 30 days growth was statistically non-significant.

\section{Dry matter yield (g plant $\left.{ }^{-1}\right)$ at 60 DAP}

The perusal of the data presented in Figure 2 showed that the addition of increasing levels of sewage sludge significantly increased the dry matter yield of rice plant at 60 days. Application of sewage sludge @ $10 \mathrm{t} \mathrm{ha}^{-1}$ increased the dry matter yield of rice plant by $26.9 \%$ over control. Application of successive levels of RDF significantly increased the dry matter yield of rice plant up to $100 \% \mathrm{RDF}$ level. Further application of RDF did not influence the dry matter yield significantly. Application of $100 \%$ RDF increased the dry matter yield by $31.1 \%$ over control.

Interaction between sewage sludge and RDF for dry matter yield of rice plant at 60 days growth was found to be significant. Maximum dry matter yield $\left(26.20 \mathrm{~g}\right.$ plant $\left.^{-1}\right)$ was obtained when sewage sludge @ $10 \mathrm{t} \mathrm{ha}^{-1}$ and $125 \%$ RDF was applied, however it was significantly at par with combined application of sewage sludge $10 \mathrm{t} \mathrm{ha}^{-1}$ and $100 \% \mathrm{RDF}$ treatment. This result was also in agreement with the findings of Kamal et al.,(2013) who reported that the sewage sludge at the different rates showed that the number of filled grains per panicle, dry weight of grains and weight of 1000 grains of rice (Oryza sativa L.) were the significantly highest where 240 tons of sewage sludge per hectare was added. The contents of $\mathrm{N}, \mathrm{P}, \mathrm{K}, \mathrm{Ca}, \mathrm{Mg}, \mathrm{Fe}$, $\mathrm{Cu}, \mathrm{Zn}$ and $\mathrm{Pb}$ in rice grains increased significantly with increasing rate of sewage sludge application.

\section{Dry matter yield (g plant ${ }^{-1}$ ) at 90 DAP}

The data on dry matter yield of rice plants at 90 days growth are given in Table 2 revealed that the addition of increasing levels of sewage sludge significantly increased the dry matter yield of rice plant at 90 days. Application of sewage sludge @ $10 \mathrm{t} \mathrm{ha}^{-1}$ increased the dry matter yield of rice plant by $30.3 \%$ over control. Application of successive levels of RDF significantly increased the dry matter yield of rice plant up to $100 \%$ RDF level. Further application of RDF did not affect the dry matter yield significantly. Application of $100 \%$ RDF increased the dry matter yield by $28.2 \%$ over control. Interaction between sewage sludge and RDF for dry matter yield of rice plant at 90 days growth was found to be significant. Maximum 
dry matter yield (28.90 g plant $\left.^{-1}\right)$ was noticed when sewage sludge @ $10 \mathrm{t} \mathrm{ha}^{-1}$ and $125 \%$ RDF was applied, however it was significantly at par with combined application of sewage sludge $10 \mathrm{t} \mathrm{ha}^{-1}$ and $100 \% \mathrm{RDF}$ treatment.

\section{Plant height (cm)}

The data on plant height of rice are given in Table 3 indicated that the addition of increasing levels of sewage sludge significantly increased the plant height. The maximum plant height $(90.96 \mathrm{~cm})$ of rice was noticed with the application sewage sludge @ $10 \mathrm{t} \mathrm{ha}^{-1}$ which was $14.5 \%$ higher than control. Application of increasing levels of RDF significantly increased the plant height of rice up to $100 \%$ RDF level. Further application of RDF did not affect the plant height significantly. Application of $100 \%$ RDF increased the plant height by $8 \%$ over control. Interaction between sewage sludge and RDF for plant height of rice plant was found to be non-significant.

\section{0 grain weight (Test weight)}

The perusal of the data presented given in Table 4 showed that the addition of increasing levels of sewage sludge significantly increased the 1000 grain weight in rice. Application of sewage sludge @ $10 \mathrm{t} \mathrm{ha}^{-1}$ increased the grain weight of rice by $10.2 \%$ over control. Application of successive levels of RDF significantly enhanced the 1000 grain weight in rice plant up to $100 \%$ RDF level. Further application of RDF did not influence the grain weight significantly. Application of $100 \%$ RDF increased the grain weight by $14.3 \%$ over control. Interaction between sewage sludge and RDF for grain weight of rice plant was found to be non-significant. Latare and Singh (2013) conducted a greenhouse study to find out the effect of conjoint application of sewage sludge and fertilizers on yield and heavy metals accumulation in rice. Results of this study showed a significant increase in test weight and grain and straw yield. About 33 and $46 \%$ increase in grain yield was observed over control that shows a possible impact on this experiment.

\section{Number of effective tillers plant ${ }^{-1}$}

The data on number of effective tillers plant ${ }^{1}$ of rice is given in Table 5 indicated that the addition of increasing levels of sewage sludge significantly increased the number of effective tillers plant ${ }^{-1}$. Application of sewage sludge @ $10 \mathrm{t} \mathrm{ha}^{-1}$ increased the number of effective tillers plant ${ }^{-1}$ of rice plant by $31.1 \%$ over control. Application of elevated levels of RDF significantly increased the number of effective tillers plant ${ }^{-1}$ of rice plant up to $100 \%$ RDF level. Further application of RDF did not affect the effective tillers plant $^{-1}$ significantly. Application of $100 \%$ RDF increased the effective tillers plant ${ }^{-1}$ by $25.6 \%$ over control. Interaction between sewage sludge and RDF of effective tillers plant ${ }^{-1}$ was found to be non-significant.

\section{Length of panicle $(\mathrm{cm})$}

The perusal of the data presented in Table 6 showed that the addition of increasing levels of sewage sludge significantly increased the length of panicle. Application of sewage sludge@10 t ha ${ }^{-1}$ increased the length of panicle of rice plant by $31.7 \%$ over control. Application of successive levels of RDF significantly increased the length of panicle of rice plant up to $100 \% \mathrm{RDF}$ level.

Further application of RDF did not affect the length of panicle significantly. Application of $100 \%$ RDF increased the length of panicle by $34.5 \%$ over control. Interaction between sewage sludge and RDF for length of panicle of rice plant was found to be significant. 
Maximum length of panicle $(12.9 \mathrm{~cm})$ was obtained when sewage sludge @ $10 \mathrm{t} \mathrm{ha}^{-1}$ and $125 \%$ RDF was applied however it was significantly at par with sewage sludge $10 \mathrm{t}$ $\mathrm{ha}^{-1}$ and $100 \%$ RDF treatment.Kamal et al.,(2013)reported that the sewage sludge at the rate of $0,40,80,120$ and $240 \mathrm{t} /$ ha showed that the number of filled grains per panicle, dry weight of grains and weight of 1000 grains of rice (Oryza sativa L.) were the significantly highest where 240 tons of sewage sludge per hectare was added.

\section{Grain yield $\left(\mathrm{kg} \mathrm{ha}^{-1}\right)$ of rice}

The data on grain yield of rice are given in Figure 3 depicted that the addition of increasing levels of sewage sludge significantly increased the grain yield of rice. Application of sewage sludge @ $10 \mathrm{t} \mathrm{ha}^{-1}$ increased grain yield of rice by $27.9 \%$ over control. Ghoneim (2007) reported that application of poultry manure and sewage sludge increased grain yield 34.8 and $38.3 \%$, respectively over control.

Table.1 Composition of sewage sludge

\begin{tabular}{|l|l|l|}
\hline Properties & Value & \multicolumn{1}{|c|}{ References } \\
\hline $\mathrm{pH}\left(1: 5 \mathrm{sludge}_{\text {water suspension })}\right.$ & 7.05 & Jackson (1973) \\
\hline $\mathrm{EC}\left(\mathrm{dSm}^{-1}\right)$ & 2.14 & Jackson (1973) \\
\hline Organic carbon $(\%)$ & 10.2 & Walkley - Black method (1934) \\
\hline Available N $(\%)$ & 2.41 & $\begin{array}{l}\text { Alkaline permanganate method by Subbiah } \\
\text { and Asija (1956) }\end{array}$ \\
\hline Available P $(\%)$ & 1.68 & Olsen et al., (1954) \\
\hline Available K $(\%)$ & 0.22 & $\begin{array}{l}\text { Flame Photometer Method by } \\
\text { Jackson (1973) }\end{array}$ \\
\hline Fe $\left(\mathrm{mg} \mathrm{kg}^{-1}\right)$ & 40.2 & $\begin{array}{l}\text { DTPA extraction method } \\
\text { Lindsay and Norvell(1978) }\end{array}$ \\
\hline $\mathrm{Zn}\left(\mathrm{mg} \mathrm{kg}^{-1}\right)$ & 15.0 & $\begin{array}{l}\text { DTPA extraction method } \\
\text { Lindsay and Norvell(1978) }\end{array}$ \\
\hline $\mathrm{Mn}\left(\mathrm{mg} \mathrm{kg}^{-1}\right)$ & 22.2 & $\begin{array}{l}\text { DTPA extraction method } \\
\text { Lindsay and Norvell(1978) }\end{array}$ \\
\hline $\mathrm{Cu}\left(\mathrm{mg} \mathrm{kg}^{-1}\right)$ & 3.4 & $\begin{array}{l}\text { DTPA extraction method } \\
\text { Lindsay and Norvell(1978) }\end{array}$ \\
\hline
\end{tabular}

Table.2 Effect of sewage sludge and RDF levels on dry matter yield (g plant ${ }^{-1}$ ) at 90 DAP

\begin{tabular}{|c|c|c|c|c|}
\hline \multirow[t]{2}{*}{ Levels of RDF } & \multicolumn{4}{|c|}{ Level of sewage sludge $\left(\mathrm{t} \mathrm{ha}^{-1}\right)$} \\
\hline & $\mathbf{S}_{\mathbf{0}}$ & $\mathbf{S}_{5}$ & $\mathbf{S}_{10}$ & Mean \\
\hline $\mathbf{R D F}_{\mathbf{0}}$ & 17.1 & 19.0 & 21.2 & 19.1 \\
\hline $\mathbf{R D F}_{\mathbf{7 5} \%}$ & 19.8 & 21.5 & 24.7 & 22.0 \\
\hline $\mathbf{R D F}_{100 \%}$ & 20.7 & 24.3 & 28.4 & 24.5 \\
\hline $\mathbf{R D F}_{125 \%}$ & 21.6 & 25.3 & 28.9 & 25.3 \\
\hline \multirow[t]{2}{*}{ Mean } & 19.8 & 22.5 & 25.8 & \\
\hline & RDF & $\mathbf{S}$ & \multicolumn{2}{|c|}{ S×RDF } \\
\hline $\mathrm{SE}(\mathrm{m}) \pm$ & 0.29 & 0.25 & \multicolumn{2}{|c|}{$\mathbf{0 . 5 0}$} \\
\hline CD 5\% & 0.84 & 0.73 & \multicolumn{2}{|c|}{$\mathbf{1 . 4 5}$} \\
\hline
\end{tabular}


Table.3 Effect of sewage sludge and RDF levels on plant height $(\mathrm{cm})$

\begin{tabular}{|l|c|c|c|c|}
\hline \multirow{2}{*}{ Levels of RDF } & \multicolumn{4}{|c|}{ Level of sewage sludge $\left(\mathbf{t ~ h a}^{-\mathbf{1}}\right)$} \\
\cline { 2 - 5 } & $\mathbf{S}_{\mathbf{0}}$ & $\mathbf{S}_{\mathbf{5}}$ & $\mathbf{S}_{\mathbf{1 0}}$ & Mean \\
\hline $\mathrm{RDF}_{0}$ & 73.44 & 80.20 & 87.27 & $\mathbf{8 0 . 3 0}$ \\
\hline $\mathrm{RDF}_{75 \%}$ & 80.10 & 85.43 & 90.46 & $\mathbf{8 5 . 3 3}$ \\
\hline $\mathrm{RDF}_{100 \%}$ & 81.33 & 86.40 & 92.60 & $\mathbf{8 6 . 7 8}$ \\
\hline $\mathrm{RDF}_{125 \%}$ & 82.87 & 87.69 & 93.53 & $\mathbf{8 8 . 0 3}$ \\
\hline Mean & $\mathbf{7 9 . 4 3}$ & $\mathbf{8 4 . 9 3}$ & $\mathbf{9 0 . 9 6}$ & \\
\hline & $\mathbf{R D F}$ & $\mathbf{S}$ & \multicolumn{2}{|c|}{$\mathbf{S \times R D F}$} \\
\hline SE (m) \pm & $\mathbf{0 . 6 0}$ & $\mathbf{0 . 5 2}$ & \multicolumn{2}{|c|}{$\mathbf{1 . 0 4}$} \\
\hline CD 5\% & $\mathbf{1 . 7 6}$ & $\mathbf{1 . 5 2}$ & \multicolumn{2}{|c|}{$\mathbf{N S}$} \\
\hline
\end{tabular}

Table.4 Effect of sewage sludge and RDF levels on 1000 grain weight $(\mathrm{g})$ of rice

\begin{tabular}{|c|c|c|c|c|}
\hline \multirow[t]{2}{*}{ Levels of RDF } & \multicolumn{4}{|c|}{ Level of sewage sludge $\left(\mathrm{t} \mathrm{ha}^{-1}\right)$} \\
\hline & $\mathbf{S}_{\mathbf{0}}$ & $\mathbf{S}_{5}$ & $\mathbf{S}_{10}$ & Mean \\
\hline $\mathbf{R D F}_{\mathbf{0}}$ & 18.4 & 19.1 & 20.9 & 19.5 \\
\hline $\mathbf{R D F}_{75 \%}$ & 20.6 & 21.4 & 22.2 & 21.4 \\
\hline $\mathbf{R D F}_{100 \%}$ & 21.2 & 22.4 & 23.2 & 22.3 \\
\hline $\mathbf{R D F}_{125 \%}$ & 21.9 & 23.1 & 24.2 & 23.1 \\
\hline \multirow[t]{2}{*}{ Mean } & 20.5 & 21.5 & 22.6 & \\
\hline & RDF & $\mathbf{S}$ & \multicolumn{2}{|c|}{ S $\times \mathbf{R D F}$} \\
\hline SE $(\mathbf{m}) \pm$ & 0.28 & 0.25 & \multicolumn{2}{|c|}{0.49} \\
\hline CD 5\% & 0.83 & 0.72 & \multicolumn{2}{|c|}{ NS } \\
\hline
\end{tabular}

Table.5 Effect of sewage sludge and RDF levels on number of effective tillers plant ${ }^{-1}$

\begin{tabular}{|c|c|c|c|c|}
\hline \multirow[t]{2}{*}{ Levels of RDF } & \multicolumn{4}{|c|}{ Level of sewage sludge ( $\mathrm{tha}^{-1}$ ) } \\
\hline & $\mathbf{S}_{\mathbf{0}}$ & $\mathbf{S}_{5}$ & $S_{10}$ & Mean \\
\hline $\mathbf{R D F}_{\mathbf{0}}$ & 6.8 & 8.4 & 9.2 & 8.2 \\
\hline $\mathbf{R D F}_{75 \%}$ & 8.1 & 9.6 & 10.8 & 9.5 \\
\hline $\mathbf{R D F}_{100 \%}$ & 9.1 & 10.3 & 11.5 & 10.3 \\
\hline $\mathbf{R D F}_{125 \%}$ & 9.4 & 10.4 & 12.1 & 10.7 \\
\hline Mean & 8.3 & 9.7 & 10.9 & \\
\hline & RDF & $\mathbf{S}$ & \multicolumn{2}{|c|}{ S $\times$ RDF } \\
\hline SE $(\mathbf{m}) \pm$ & 0.17 & 0.15 & \multicolumn{2}{|c|}{0.30} \\
\hline CD 5\% & 0.51 & 0.44 & \multicolumn{2}{|c|}{ NS } \\
\hline
\end{tabular}

Table.6 Effect of sewage sludge and RDF levels on length of panicle $(\mathrm{cm})$

\begin{tabular}{|c|c|c|c|c|}
\hline \multirow[t]{2}{*}{ Levels of RDF } & \multicolumn{4}{|c|}{ Level of sewage sludge $\left(\mathrm{t} \mathrm{ha}^{-1}\right)$} \\
\hline & $S_{0}$ & $\mathbf{S}_{5}$ & $S_{10}$ & Mean \\
\hline $\mathbf{R D F}_{\mathbf{0}}$ & 7.5 & 8.1 & 8.8 & 8.1 \\
\hline $\mathbf{R D F}_{75 \%}$ & 8.1 & 9.2 & 10.7 & 9.4 \\
\hline $\mathbf{R D F}_{\mathbf{1 0 0} \%}$ & 9.1 & 11.3 & 12.4 & 10.9 \\
\hline $\mathbf{R D F}_{125 \%}$ & 9.4 & 11.7 & 12.9 & $\mathbf{1 1 . 3}$ \\
\hline Mean & 8.5 & $\mathbf{1 0 . 1}$ & $\mathbf{1 1 . 2}$ & \\
\hline & RDF & $\mathbf{S}$ & & \\
\hline SE $(\mathbf{m}) \pm$ & 0.18 & 0.15 & & \\
\hline CD 5\% & $\mathbf{0 . 5 2}$ & 0.45 & & \\
\hline
\end{tabular}


Table.7 Uptake of nitrogen $\left(\mathrm{kg} \mathrm{ha}^{-1}\right)$ by grain of rice after application of Sewage sludge

\begin{tabular}{|l|c|c|c|c|}
\hline \multirow{2}{*}{ Levels of RDF } & \multicolumn{4}{|c|}{ Level of sewage sludge $\left(\mathbf{t h a}^{-\mathbf{1}}\right)$} \\
\cline { 2 - 5 } & $\mathbf{S}_{\mathbf{0}}$ & $\mathbf{S}_{\mathbf{5}}$ & $\mathbf{S}_{\mathbf{1 0}}$ & Mean \\
\hline RDF $_{\mathbf{0}}$ & 8.33 & 13.01 & 17.39 & $\mathbf{1 2 . 9 1}$ \\
\hline RDF $_{\mathbf{7 5} \%}$ & 17.69 & 19.76 & 24.53 & $\mathbf{2 0 . 6 6}$ \\
\hline RDF $_{\mathbf{1 0 0} \%}$ & 22.46 & 26.51 & 31.39 & $\mathbf{2 6 . 7 9}$ \\
\hline RDF $_{\mathbf{1 2 5} \%}$ & 23.98 & 27.44 & 32.15 & $\mathbf{2 7 . 8 5}$ \\
\hline Mean & $\mathbf{1 8 . 1 2}$ & $\mathbf{2 1 . 6 8}$ & $\mathbf{2 6 . 3 6}$ & \\
\hline & $\mathbf{R D F}$ & $\mathbf{S}$ & \multicolumn{2}{|c|}{ S $\times$ RDF } \\
\hline SE (m) \pm & $\mathbf{0 . 3 7}$ & $\mathbf{0 . 3 2}$ & \multicolumn{2}{|c|}{$\mathbf{0 . 6 5}$} \\
\hline CD 5\% & $\mathbf{1 . 1 0}$ & $\mathbf{0 . 9 5}$ & \multicolumn{2}{|c|}{ NS } \\
\hline
\end{tabular}

Table.8 Uptake of phosphorus $\left(\mathrm{kg} \mathrm{ha}^{-1}\right)$ by grain of rice after application of Sewage sludge

\begin{tabular}{|c|c|c|c|c|}
\hline \multirow{2}{*}{ Levels of RDF } & \multicolumn{4}{|c|}{ Level of sewage sludge $\left(\mathrm{t} \mathrm{ha}^{-1}\right)$} \\
\hline & $S_{0}$ & $S_{5}$ & $\mathbf{S}_{10}$ & Mean \\
\hline $\mathrm{RDF}_{\mathbf{0}}$ & 1.09 & 1.93 & 2.54 & 1.86 \\
\hline $\mathbf{R D F}_{75 \%}$ & 2.35 & 2.76 & 3.89 & 3.00 \\
\hline $\mathbf{R D F}_{100 \%}$ & 3.53 & 4.08 & 5.79 & 4.47 \\
\hline $\mathbf{R D F}_{125 \%}$ & 3.92 & 4.69 & 6.41 & 5.01 \\
\hline \multirow[t]{2}{*}{ Mean } & 2.72 & $\mathbf{3 . 3 7}$ & 4.66 & \\
\hline & RDF & $\mathbf{S}$ & \multicolumn{2}{|c|}{ S $\times$ RDF } \\
\hline SE (m) \pm & 0.22 & 0.19 & \multicolumn{2}{|c|}{0.38} \\
\hline CD 5\% & 0.64 & 0.55 & \multicolumn{2}{|c|}{ NS } \\
\hline
\end{tabular}

Table.9 Uptake of potassium $\left(\mathrm{kg} \mathrm{ha}^{-1}\right)$ by rice grain after application of Sewage sludge

\begin{tabular}{|c|c|c|c|c|}
\hline \multirow{2}{*}{ Levels of RDF } & \multicolumn{4}{|c|}{ Level of sewage sludge $\left(\mathrm{t} \mathrm{ha}^{-1}\right)$} \\
\hline & $S_{0}$ & $\mathbf{S}_{5}$ & $S_{10}$ & Mean \\
\hline $\mathbf{R D F}_{\mathbf{0}}$ & 2.18 & 3.61 & 4.93 & 3.57 \\
\hline $\mathbf{R D F}_{75 \%}$ & 5.00 & 5.81 & 7.35 & 6.05 \\
\hline $\mathbf{R D F}_{100 \%}$ & 6.70 & 7.70 & 9.65 & 8.02 \\
\hline $\mathbf{R D F}_{125 \%}$ & 7.46 & 8.09 & 10.26 & 8.60 \\
\hline Mean & 5.34 & 6.30 & 8.05 & \\
\hline & RDF & $\mathbf{S}$ & \multicolumn{2}{|c|}{ S $\times \mathbf{R D F}$} \\
\hline SE $(\mathbf{m}) \pm$ & 0.20 & 0.17 & \multicolumn{2}{|c|}{0.35} \\
\hline CD 5\% & 0.59 & 0.51 & \multicolumn{2}{|c|}{ NS } \\
\hline
\end{tabular}

Table.10 Effect of sewage sludge and RDF levels on uptake of zinc $\left(\mathrm{g} \mathrm{ha}^{-1}\right)$ by grain of rice

\begin{tabular}{|l|l|l|l|l|}
\hline \multirow{2}{*}{ Levels of RDF } & \multicolumn{4}{|l|}{ Level of sewage sludge $\left(\mathbf{t ~ h a}^{-\mathbf{1}}\right)$} \\
\cline { 2 - 5 } & $\mathbf{S}_{\mathbf{0}}$ & $\mathbf{S}_{\mathbf{5}}$ & $\mathbf{S}_{\mathbf{1 0}}$ & Mean \\
\hline $\mathbf{R D F}_{\mathbf{0}}$ & 14.00 & 24.86 & 34.83 & $\mathbf{2 4 . 5 7}$ \\
\hline $\mathbf{R D F}_{\mathbf{7 5} \%}$ & 26.14 & 33.86 & 43.30 & $\mathbf{3 4 . 4 4}$ \\
\hline RDF $_{\mathbf{1 0 0} \%}$ & 31.44 & 43.45 & 55.06 & $\mathbf{4 3 . 3 2}$ \\
\hline RDF $_{\mathbf{1 2 5} \%}$ & 33.13 & 45.55 & 56.92 & $\mathbf{4 5 . 2 0}$ \\
\hline Mean & $\mathbf{2 6 . 1 8}$ & $\mathbf{3 6 . 9 3}$ & $\mathbf{4 7 . 5 3}$ & \\
\hline & $\mathbf{R D F}$ & $\mathbf{S}$ & $\mathbf{S} \times \mathbf{R D F}$ & \\
\hline SE $(\mathbf{m}) \pm$ & $\mathbf{1 . 0 1}$ & $\mathbf{1 . 1 7}$ & $\mathbf{2 . 0 2}$ & \\
\hline CD 5\% & $\mathbf{2 . 9 7}$ & $\mathbf{3 . 4 3}$ & $\mathbf{N S}$ & \\
\hline
\end{tabular}


Table.11 Uptake of manganese $\left(\mathrm{g} \mathrm{ha}^{-1}\right)$ by grain of rice

\begin{tabular}{|l|c|c|c|c|}
\hline \multirow{2}{*}{ Levels of RDF } & \multicolumn{4}{|c|}{ Level of sewage sludge $\left(\mathbf{t ~ h a}^{\mathbf{- 1}}\right)$} \\
\cline { 2 - 5 } & $\mathbf{S}_{\mathbf{0}}$ & $\mathbf{S}_{\mathbf{5}}$ & $\mathbf{S}_{\mathbf{1 0}}$ & Mean \\
\hline RDF $_{\mathbf{0}}$ & 31.61 & 51.12 & 68.20 & $\mathbf{5 0 . 3 1}$ \\
\hline RDF $_{\mathbf{7 5} \%}$ & 58.95 & 69.23 & 84.67 & $\mathbf{7 0 . 9 5}$ \\
\hline RDF $_{\mathbf{1 0 0 \%}}$ & 70.64 & 87.51 & 107.22 & $\mathbf{8 8 . 4 6}$ \\
\hline RDF $_{\mathbf{1 2 5} \%}$ & 74.60 & 90.34 & 109.71 & $\mathbf{9 1 . 5 5}$ \\
\hline Mean & $\mathbf{5 8 . 9 5}$ & $\mathbf{7 4 . 5 5}$ & $\mathbf{9 2 . 4 5}$ & S RDF \\
\hline & RDF & S & \multicolumn{2}{|c|}{$\mathbf{2 . 1 4}$} \\
\hline SE (m) \pm & $\mathbf{1 . 0 7}$ & $\mathbf{1 . 2 4}$ & \multicolumn{3}{|c|}{ NS } \\
\hline CD 5\% & $\mathbf{3 . 1 4}$ & $\mathbf{3 . 6 3}$ & \multicolumn{4}{|c|}{} \\
\hline
\end{tabular}

Table.12 Uptake of copper $\left(\mathrm{g} \mathrm{ha}^{-1}\right)$ by grain of rice

\begin{tabular}{|l|c|c|c|c|}
\hline \multirow{2}{*}{ Levels of RDF } & \multicolumn{5}{|c|}{ Level of sewage sludge $\left(\mathbf{t ~ h a}^{\mathbf{- 1}}\right)$} \\
\cline { 2 - 5 } & $\mathbf{S}_{\mathbf{0}}$ & $\mathbf{S}_{\mathbf{5}}$ & $\mathbf{S}_{\mathbf{1 0}}$ & Mean \\
\hline RDF $_{\mathbf{0}}$ & 2.33 & 5.18 & 7.29 & $\mathbf{4 . 9 3}$ \\
\hline RDF $_{\mathbf{7 5} \%}$ & 4.60 & 7.12 & 9.45 & $\mathbf{7 . 0 6}$ \\
\hline RDF $_{\mathbf{1 0 0} \%}$ & 5.81 & 9.18 & 12.00 & $\mathbf{8 . 9 9}$ \\
\hline RDF $_{\mathbf{1 2 5} \%}$ & 6.21 & 9.56 & 12.51 & $\mathbf{9 . 4 3}$ \\
\hline Mean & $\mathbf{4 . 7 4}$ & $\mathbf{7 . 7 6}$ & $\mathbf{1 0 . 3 1}$ & \\
\hline SE (m) \pm & RDF & S & S $\times$ RDF \\
\hline CD 5\% & $\mathbf{0 . 2 6}$ & $\mathbf{0 . 3 0}$ & \multicolumn{2}{c|}{$\mathbf{0 . 5 2}$} \\
\hline & $\mathbf{0 . 7 7}$ & $\mathbf{0 . 8 9}$ & \multicolumn{4}{c|}{ NS } \\
\hline
\end{tabular}

Table.13 Effect of sewage sludge and RDF levels on uptake of iron $\left(\mathrm{g} \mathrm{ha}^{-1}\right)$ by grain of rice

\begin{tabular}{|l|c|c|c|c|}
\hline \multirow{2}{*}{ Levels of RDF } & \multicolumn{4}{|c|}{ Level of sewage sludge $\left(\mathbf{t ~ h a}^{\mathbf{- 1}}\right)$} \\
\cline { 2 - 5 } & $\mathbf{S}_{\mathbf{0}}$ & $\mathbf{S}_{\mathbf{5}}$ & $\mathbf{S}_{\mathbf{1 0}}$ & Mean \\
\hline RDF $_{\mathbf{0}}$ & 39.13 & 61.71 & 82.16 & $\mathbf{6 1 . 0 0}$ \\
\hline RDF $_{\mathbf{7 5} \%}$ & 73.53 & 83.56 & 102.64 & $\mathbf{8 6 . 5 8}$ \\
\hline RDF $_{\mathbf{1 0 0} \%}$ & 88.15 & 105.94 & 128.98 & $\mathbf{1 0 7 . 6 9}$ \\
\hline RDF $_{\mathbf{1 2 5} \%}$ & 93.38 & 108.78 & 132.18 & $\mathbf{1 1 1 . 4 4}$ \\
\hline Mean & $\mathbf{7 3 . 5 5}$ & $\mathbf{9 0 . 0 0}$ & $\mathbf{1 1 1 . 4 9}$ & $\mathbf{2}$ \\
\hline & $\mathbf{R D F}$ & $\mathbf{S} \times \mathbf{R D F}$ \\
\hline SE (m) $\mathbf{\pm}$ & $\mathbf{1 . 4 3}$ & $\mathbf{1 . 6 5}$ & \multicolumn{2}{|c|}{$\mathbf{2 . 8 5}$} \\
\hline CD 5\% & $\mathbf{4 . 1 9}$ & $\mathbf{4 . 8 3}$ & \multicolumn{3}{|c|}{} \\
\hline
\end{tabular}


Fig.1 Dry matter yield $\left(\mathrm{g} \mathrm{plant}^{-1}\right)$ at $30 \mathrm{DAP}$

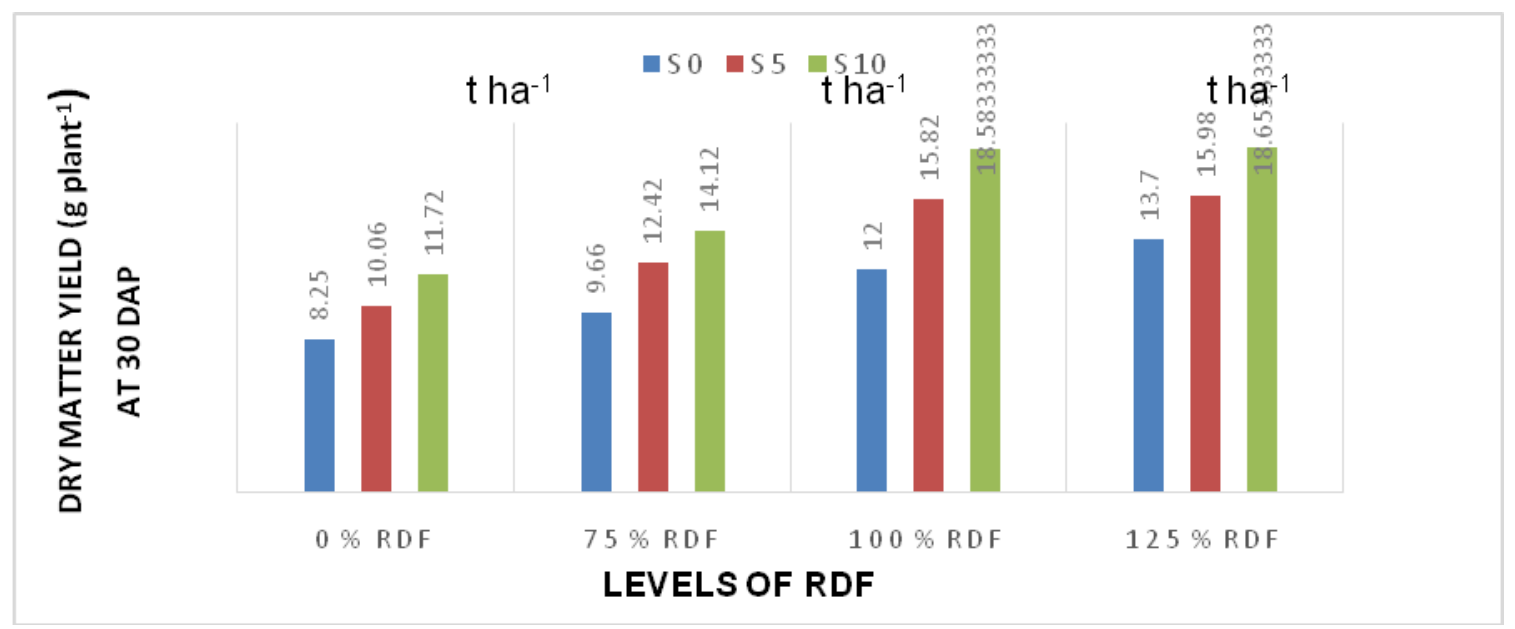

Fig.2 Dry matter yield (g plant $\left.{ }^{-1}\right)$ at 60 DAP

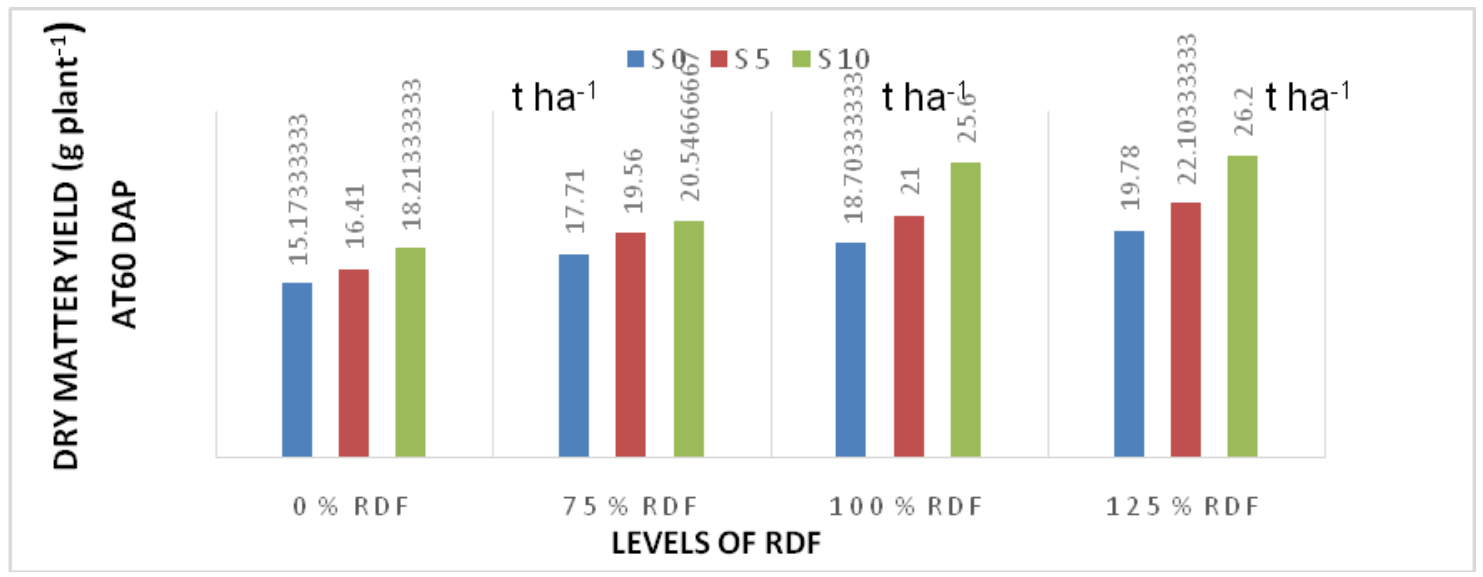

Fig.3 Grain yield with various level of RDF

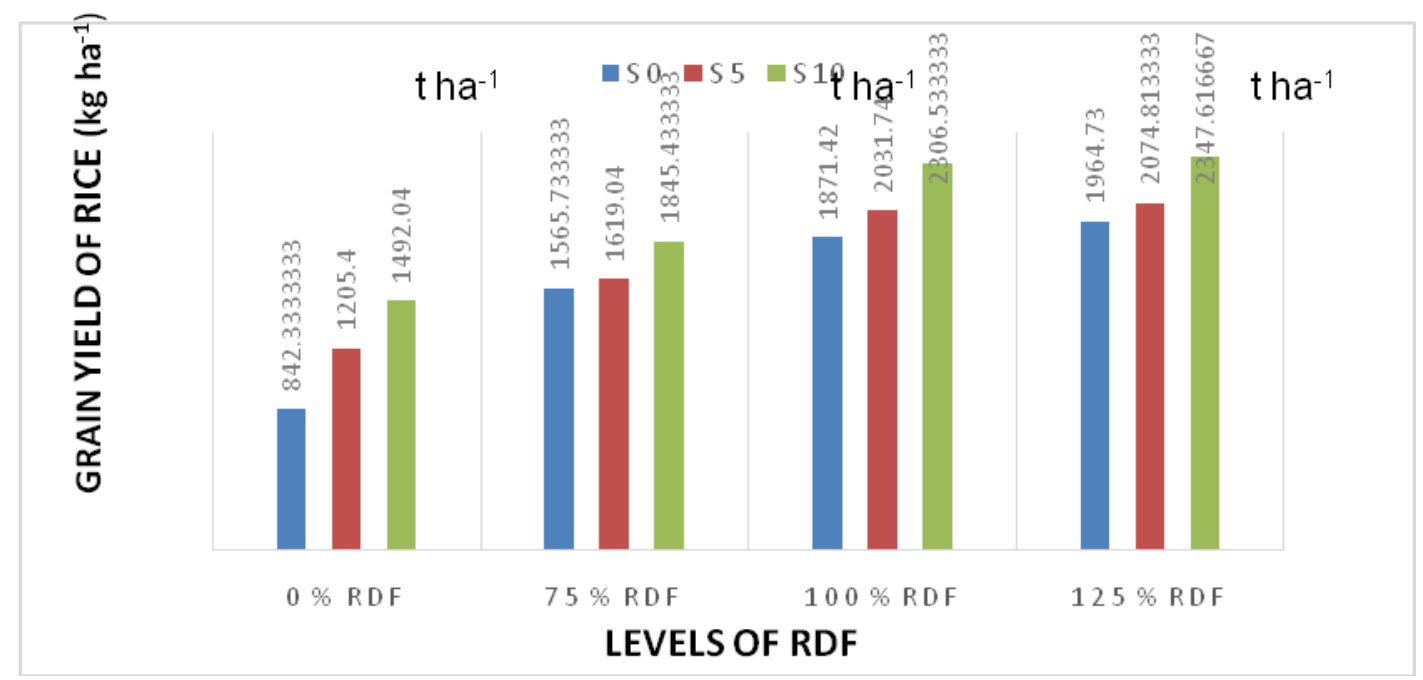


Fig.4 Uptake of N with various level of RDF

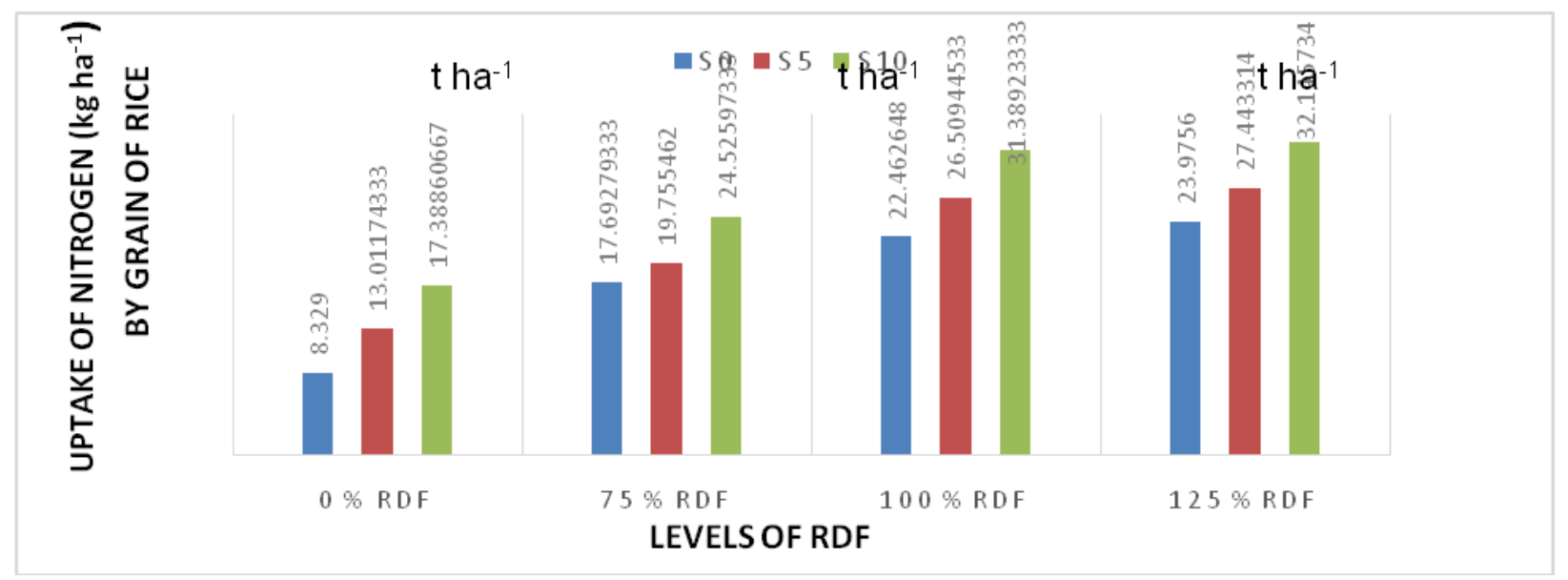

Fig.5 Uptake P with various dose of RDF

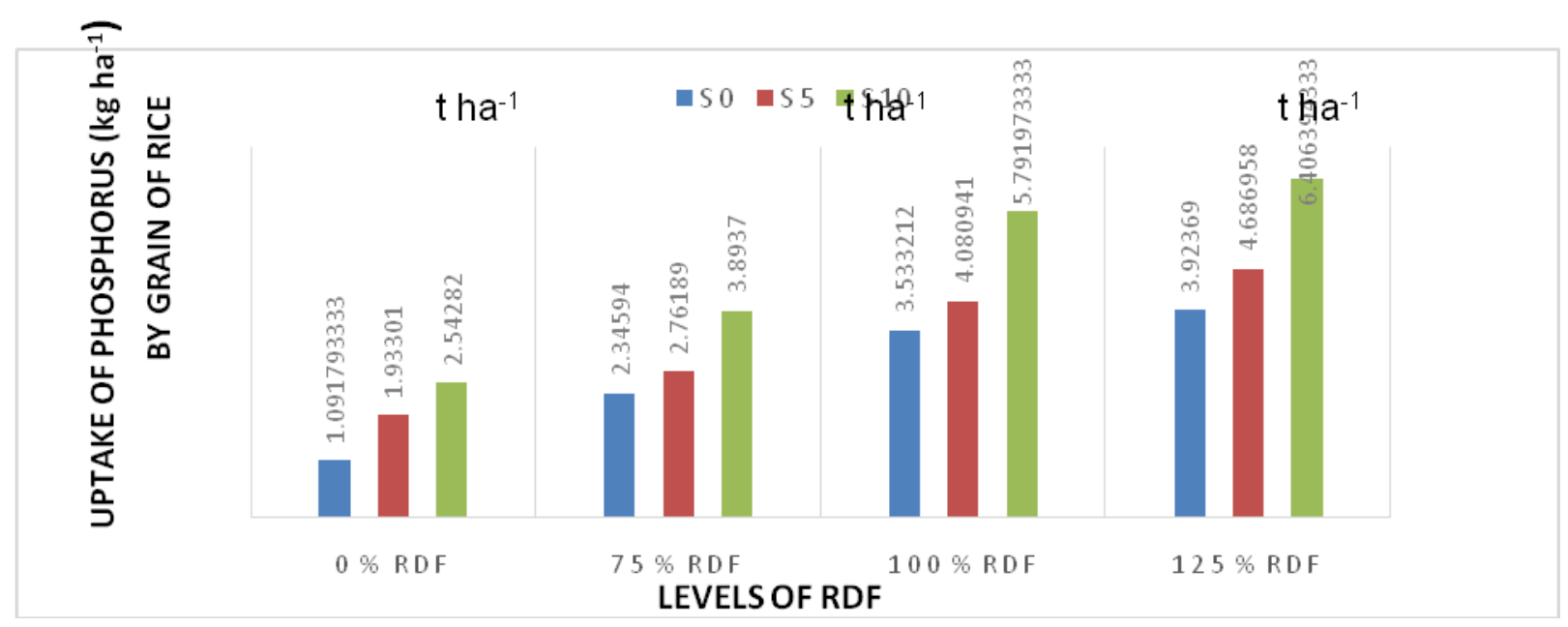

Fig.6 Uptake of K with various level of RDF

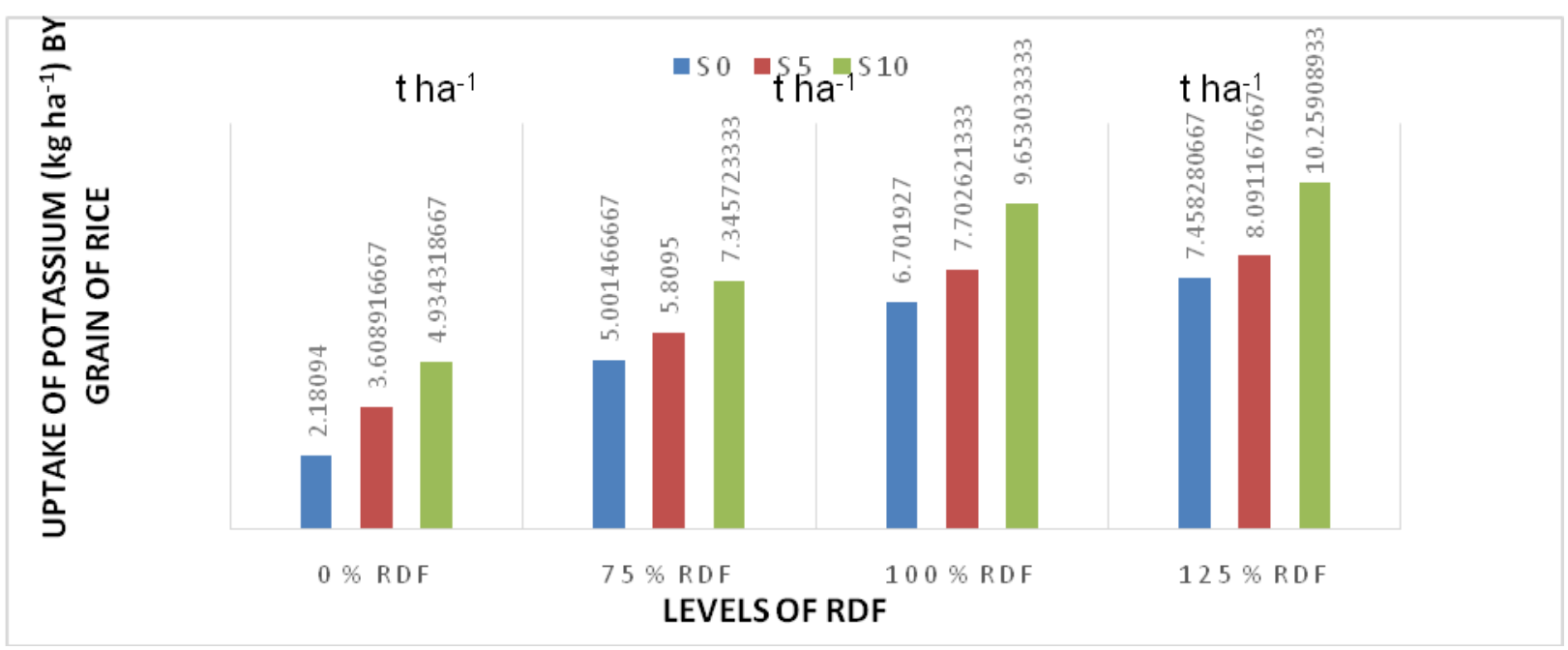


Application of successive levels of RDF significantly increased the grain yield of rice up to $100 \%$ RDF level. Further application of RDF did not influence the grain yield significantly. Application of $100 \%$ RDF increased the grain yield by $75.4 \%$ over control.

Interaction between sewage sludge and RDF for grain yield of rice was found to be significant. Maximum grain yield $(2347.6 \mathrm{~kg}$ ha-1)was recorded when sewage sludge @ 10 $\mathrm{t} \mathrm{ha}^{-1}$ and $125 \%$ RDF was applied however it was significantly at par with sewage sludge $10 \mathrm{t} \mathrm{ha}^{-1}$ and $100 \%$ RDF treatment. Gupta et al., (1993) reported that the grain and straw yield of wheat increased with the application of sewage sludge.

\section{Nutrient Uptake}

\section{Uptake of nitrogen $\left(\mathrm{kg} \mathrm{ha}^{-1}\right)$ by grain of rice}

The data on the uptake of nitrogen by grain as affected by the different treatments are presented in table 7 and Figure 4 showed that the application of increasing levels of sewage sludge significantly increased the uptake of nitrogen by grain of rice as compared to control. Maximum uptake of nitrogen (26.36 $\mathrm{kg} \mathrm{ha}{ }^{-1}$ ) by grain was obtained with the application of sewage sludge @ $10 \mathrm{t} \mathrm{ha}^{-1}$ which was significantly higher over all the other levels of sewage sludge. Application of different levels of RDF significantly improved the uptake of nitrogen by grain of rice. Maximum uptake of nitrogen $(27.85 \mathrm{~kg}$ $\mathrm{ha}^{-1}$ ) by grain was found with $125 \% \mathrm{RDF}$ which was at par with $100 \%$ RDF. Ahmed et al., (2010) reported that the application of sewage sludge to the calcareous soil lowered the $\mathrm{pH}$ of the soil, although the value always around 7.75-7.9 at the end of the experiment. In the barley plants it was observed that the higher the yield, the higher the nitrogen contents. Interaction between sewage sludge and RDF for uptake of nitrogen by grain was found to be non-significant.

\section{Uptake of phosphorus $\left(\mathrm{kg} \mathrm{ha}^{-1}\right)$ by grain of rice}

The results presented in Table 8 and Figure 5 showed that the addition of sewage sludge significantly increased the uptake of phosphorus by grain as compared to control. Maximum uptake of phosphorus $(4.66 \mathrm{~kg}$ ha 1) was obtained with the application of sewage sludge @ $10 \mathrm{t} \mathrm{ha}^{-1}$ which was significantly higher over all the other levels of sewage sludge. Under different RDF, application of $125 \%$ RDF showed maximum uptake of phosphorus $\left(5.01 \mathrm{~kg} \mathrm{ha}^{-1}\right)$ by grain of rice, however it was at par with $100 \%$ RDF. Interaction between sewage sludge and $\mathrm{RDF}$ for uptake of phosphorus by rice grain was found to be non-significant. Gupta et al., (1993) reported that total $\mathrm{P}$ and $\mathrm{N}$ uptake by wheat increased with the increased application of sewage sludge in wheat.

\section{Uptake of potassium $\left(\mathrm{kg} \mathrm{ha}^{-1}\right)$ by grain of rice}

The data on uptakes of potassium by grain given in table 9 and Figure 6 showed that the addition of different levels of sewage sludge significantly affected the uptake of phosphorus by straw as compared to control. Maximum uptake of potassium $\left(8.05 \mathrm{~kg} \mathrm{ha}^{-1}\right)$ by grain was noticed with the application of sewage sludge @ $10 \mathrm{t} \mathrm{ha}^{-1}$ which was significantly higher over all the other levels of sewage sludge. Application of different levels of RDF significantly improved the uptake of potassium by grain of rice.

The highest uptake of potassium $(8.60 \mathrm{~kg}$ ha $\left.{ }^{1}\right)$ was recorded by the application of $125 \%$ RDF which was at par with $100 \%$ RDF. Interaction between sewage sludge and RDF for uptake of potassium by grain was found to be non-significant. 


\section{Uptake of zinc $\left(\mathrm{g} \mathrm{ha}^{-1}\right)$ by grain of rice}

The data on uptake of zinc by grain of rice as affected by different treatment are given in Table 10. It was evident from the data that the application sewage sludge @ $10 \mathrm{t} \mathrm{ha}^{-1}$ significantly increased uptake of zinc by grain in compared to control. Maximum uptake of zinc (47.53 $\mathrm{g} \mathrm{ha}^{-1}$ ) was obtained with the application of sewage sludge @ $10 \mathrm{t} \mathrm{ha}^{-1}$ which was significantly higher over all the other levels of sewage sludge. Addition of different levels of RDF significantly increased the uptake of zinc by grain of rice. The highest uptake of zinc $\left(45.20 \mathrm{~g} \mathrm{ha}^{-1}\right)$ by grain was recorded by the application of $125 \%$ $\mathrm{RDF}$, however it was statistically at par with 100\% RDF. Togay et al., (2008) reported that the higher application rates of municipal sewage sludge caused significant increase in $\mathrm{Zn}$ concentration in seed. Interaction between sewage sludge and RDF for uptake of zinc by rice grain was found to be non-significant.

\section{Uptake of manganese $\left(\mathrm{g} \mathrm{ha}^{-1}\right)$ by grain of rice}

The data presented in Table 11 revealed that the application of $10 \mathrm{t} \mathrm{ha}^{-1}$ sewage sludge significantly increased the uptake of manganese by grain of rice. Maximum uptake of manganese $\left(92.45 \mathrm{~g} \mathrm{ha}^{-1}\right)$ was obtained with $10 \mathrm{t} \mathrm{ha}^{-1}$ sewage sludge addition. Addition of different levels of RDF significantly increased the uptake of manganese by grain of rice. The highest uptake of manganese ( $\left.91.55 \mathrm{~g} \mathrm{ha}^{-1}\right)$ by grain was recorded by the application of $125 \% \mathrm{RDF}$ however it was statistically at par with $100 \%$ RDF. Interaction between sewage sludge and RDF for uptake of manganese by grain was found to be non-significant.

\section{Uptake of copper $\left(\mathrm{g} \mathrm{ha}^{-1}\right)$ by grain of rice}

It is evident from the data presented in Table 12 showed that the application of $10 \mathrm{t} \mathrm{ha}^{-1}$ sewage sludge significantly affected the uptake of copper by grain. The highest uptake of copper $\left(10.31 \mathrm{~g} \mathrm{ha}^{-1}\right)$ was recorded with 10 $\mathrm{t} \mathrm{ha} \mathrm{A}^{-1}$ sewage sludge application. Addition of different levels of RDF significantly affected the uptake of copper by grain of rice. The highest uptake of copper $\left(9.43 \mathrm{~g} \mathrm{ha}^{-1}\right)$ by grain was recorded by the application of $125 \%$ $\mathrm{RDF}$, however it was statistically at par with $100 \%$ RDF.

\section{Uptake of iron $\left(\mathrm{g} \mathrm{ha}^{-1}\right)$ by grain of rice}

The data on uptake of iron by grain of rice as affected by different treatment are given in Table 13. It was evident from the data that the application sewage sludge @ $10 \mathrm{t} \mathrm{ha}^{-1}$ significantly increased uptake of iron by grain in compared to control.

Maximum uptake of iron (111.49 $\mathrm{g} \mathrm{ha}^{-1}$ ) was obtained with the application of sewage sludge @ $10 \mathrm{t} \mathrm{ha}^{-1}$ which was significantly higher over all the other levels of sewage sludge. Application of different levels of RDF significantly affected the uptake of iron by grain of rice. The highest uptake of iron $\left(111.44 \mathrm{~g} \mathrm{ha}^{-1}\right)$ by grain was recorded by the application of $125 \%$ RDF however it was statistically at par with $100 \% \mathrm{RDF}$.

It can be concluded from the present investigation that the application of sewage sludge produced higher grain and straw due to the more number of effective tillers and significantly higher test weight and panicle length. $10 \mathrm{t} \mathrm{ha}{ }^{-1}$ sewage sludge in combination with $100 \%$ RDF increased the productivity of rice in sodic Vertisols. It has potential to decreased the ESP and supply the nutrients to rice. Hence, application of sewage sludge may be a good preposition for improving yield and buildup of nutrients and organic carbon in sodic Vertisols. Application of sewage sludge may have save $25 \%$ of chemical fertilizers (RDF) as $125 \% \mathrm{RDF}$ is recommended for sodic Vertisols. 


\section{References}

Ahmed, H. K., Fawy, H. A. and Abdel-Hady, E. S. (2010). Study of sewage sludge use in agriculture and its effect on plant and soil. Agric. Biol. J. N. Am. 1(5): 1044-1049.

Anonymous (2012-13). Area and production in India and Madhya Pradesh.Ministry of Agriculture and Statistics, New Delhi.

Ghoneim, A. (2007). Effect of nitrogen supplied from poultry manure and sewage sludge on growth, yield and nitrogen uptake of rice. Bull. Exp. Farm Fac. Agr., Ehime Univ. 29, 11-16.

Gupta, A. P., Narwal, R. P. and Antil, R. S. (1993) Effect of different levels of phosphorus and sewage sludge on wheat. J. Indian Soc. Soil Sci. 41(2), 304-307.

Jackson, M.L. (1973). Soil Chemical Analysis, Prentice Hall of India Private Limited, New Delhi, pp. 187.

Kamal, A. T. M. M., Islam, M. M., Hossain, M. S. and Ullah, S. M. (2013). Influence of sewage sludge on yield and mineral contents of rice grains. Bangladesh J. Sci. Res. 26(1\&2): 57-60.

Latare, A. M. and Singh, S. K. (2013) Effect of sewage sludge and fertilizers application on accumulation of heavy metals and yield of Rice (Oryzasativa L.) in an Inceptisol of Varanasi. J. Indian Soc. Soil Sci. 61, 219-225.

Lindsay, W.L. and Norvell, W.A. (1978)
Development of DTPA soil test for zinc, iron, manganese and copper. Soil Sci. Soc. Am. J. 42,421-428.

Meena, M.C., Patel, K.P., Dhyan Singh and Dwivedi, B.S.(2008) Long-term effect of sewage sludge and farm yard manure on grain yields and availability of zinc and iron under pearl millet (Pennistum glaucum)- Indian mustard (Brassica juncea) cropping sequence. Indian J. Agri. Sci. 78, 1028-1032.

Olsen, S.R., C.V. Cole., P.S. Watnabe. and L.A. Dean. (1954). Estimation of available phosphorus in soil by extraction with sodium bicarbonate. USDA Circ. 939.

Singh, R.P. and Agrawal, M. (2008) Potential benefits and risks of land application of sewage sludge. Waste Management 28, 347-358.

Subbiah, B. V. and G.L. Asija. (1956). A rapid procedure for the determination of available nitrogen in soils. Current Science. 25: 259-260.

Togay, N., Togay, Y. and Dogan, Y. (2008). Effect of municipal sewage sludge doses on the yield, some yield components and heavy metals concentration of dry bean (Phaseolus Vulgaris L.). African J. Biotechnol. 7, 3026-3030.

Walkley, A. and I.A. Black. (1934). An examination of Degtjareff method for determining soil organic matter and a proposed modification of the chromic acid titration method. Soil Sci. 37: 2937.

\section{How to cite this article:}

Rahul Thakur, U.R. Khandkar, Debabrata Nath, Rohit K. Patidar and Narendra K. Patidar. 2017. Documentation on Enhancing Nutrient Uptake and Yield of Rice with Application of Sewage Sludge and Different Fertility Levels on Sodic Vertisols. Int.J.Curr.Microbiol.App.Sci. 6(10): 2986-2998. doi: https://doi.org/10.20546/ijcmas.2017.610.352 